\title{
Protein model for pollutant uptake and elimination by living organisms and its implications for ecotoxicology
}

\author{
Susan Quinnell ${ }^{1, *}$, Kees Hulsman ${ }^{1}$, Peter J. F. Davie ${ }^{2}$ \\ ${ }^{1}$ Australian School of Environmental Studies, Nathan Campus, Griffith University, Queensland 4111, Australia \\ ${ }^{2}$ Biodiversity Program, Queensland Museum, GPO Box 3300, South Brisbane, Queensland 4101, Australia
}

\begin{abstract}
The conceptual model on which chemical assessment of pollutants is based is flawed. The assumption in ecotoxicology - that pollutants cross the biological membrane only by passive diffusion of their solute phase (diffusion model) and thus, that only water-soluble pollutants are biologically available - is inconsistent with the biologists' understanding of the role and functioning of the biological membrane. The biological membrane both isolates organisms, cells and organelles from their external environments and regulates cross-membrane trafficking of polar and non-polar substances. Trafficking regulation is a function of proteins dissolved within the membrane. An alternative protein model for pollutant uptake and elimination is proposed that provides a credible explanation of how solid-phase pollutants, such as those bound to aquatic sediments and soils, may be readily incorporated by living organisms. Current chemical testing is likely to underestimate the risk posed to organisms by sediment and soil-bound pollutants. New techniques for assessing the bioavailability and impacts of pollutants, based on the protein model, are urgently needed.
\end{abstract}

KEY WORDS: Ecotoxicology $\cdot$ Pollution $\cdot$ Protein model $\cdot$ Diffusion model $\cdot 3$-phase model $\cdot$ Cell membrane $\cdot$ Equilibrium partitioning coefficient $\cdot$ Transport proteins $\cdot$ Sediment $\cdot$ Pore water

\section{INTRODUCTION}

Our interest in ecotoxicology was sparked when standard chemical tests of sediments failed to explain a widespread and sustained collapse of macrobenthic infauna (animals $\geq 0.5 \mathrm{~mm}$ living in aquatic sediments) in riverine estuaries of SE Queensland, Australia. Their catchments have become highly urbanised over the last 30 yr. Studies from 1972 to 1974 found that these estuaries supported macrobenthic infaunal densities of up to $35000 \mathrm{~m}^{-2}$, with mean abundances of $\sim 4000 \mathrm{~m}^{-2}$ (Campbell et al. 1974a,b,c, Stephenson \& Campbell 1977). More than $80 \%$ were deposit-feeders. In the same estuaries today, infaunal abundances are $<2.5 \%$ of their former values. Suspension-feeders have been less impacted than deposit-feeding organisms, but are also absent or rare in those estuaries with the largest urban/industrial catchments. Estuaries with lower vulnerability to catchment pollution have impover- ished sediment infauna, but continue to support an abundance of macrobenthos on logs that protrude above the sediments (S. Quinnell unpubl. data). These observations led us to postulate that the faunal loss was the result of contaminated sediments, rather than of water pollution. When extensive chemical testing of the sediments, based on internationally accepted protocols, failed to identify any causal agent (Miller 2000), we were forced to question whether sediment contamination was being appropriately assessed, especially the threat posed by pollutants bound to sediments and organic matter ingested by deposit-feeding infaunal organisms.

Sediments in aquatic ecosystems accumulate pollutants, with concentrations often many orders of magnitude greater than in associated water (Meador et al. 1995, Nipper 2000, Anderson et al. 2001, Burd 2002, Fent 2003). In aquatic ecosystems, benthic organisms are well-suited indicators of environmental contamina- 
tion (University North Carolina 1994, Krantzberg et al. 2000, Anderson et al. 2001), because their usually restricted mobility makes it difficult for them to escape contaminated conditions (Peso-Aguiar et al. 2000). Sediment-sorbed contaminants may profoundly impact biological communities (Morissey et al. 1996, Ferraro \& Cole 1997, Grumiaux et al. 1998, Burd et al. 2000, Peso-Aguiar et al. 2000, Stewart et al. 2000, Xu et al. 2002), with adverse ecological changes accumulating through time (Grumiaux et al. 1998). Such changes may be indicators of adverse toxic effects not identifiable by chemical tests (Stewart et al. 2000, Roach et al. 2001).

Chemical testing alone is known to be inadequate for environmental quality assessment. Some pesticides presently in use, including the synthetic pyrethroids, are lethal to fishes at sediment pore (interstitial) water concentrations $<0.2 \mathrm{ppb}$ (Siegfried 1993) and to invertebrates (especially arthropods) at $<1 \mathrm{ppb}$. This is below the standard minimum detection threshold of pore water concentrations of most organic pollutants ( $\geq 1$ ppb) (Neal et al. 1998, Stewart et al. 2000, Roach et al. 2001). Sublethal levels of toxicity that may impact food webs (Drenner 1993) are likely to be much lower (Siegfried 1993). Scientific frameworks for evaluating the ecological significance of contaminants in sediments are 'either lacking or not widely used or communicated' (Krantzberg et al. 2000, p. 388).

Ecotoxicological modelling of pollutant behaviour in ecosystems is based on the hypothesis that pollutants enter and leave living organisms (i.e. cross the external biological membrane) only by passive diffusion of their solute phase through the membrane's phospholipid bilayer (the 'diffusion model'). The corollary is that only pollutant solutes are available for uptake by living organisms (e.g. Chiou et al. 1982, Hawker \& Connell 1985, 1986, 1988a, b, Connell 1988, 1990, Markwell et al. 1989, Di Toro et al. 1990, Just et al. 1990, Stenerson 1992, De la Torre et al. 1995, Karrupiah \& Gupta 1996, Skoglund et al. 1996, Mitra \& Dickhut 1999, Carbonell et al. 2000, Chu \& Chan 2000, Maskaoui et al. 2002, Nipper et al. 2002, Williamson et al. 2002, Fent 2003). This assumption ignores an inherent primary function of the bilayer of the biological membrane - that it is an impermeable barrier which isolates any living unit (organelle, cell or living organism) from its external environment (e.g. Alberts et al. 1994, Voet et al. 1999, Madigan et al. 2003). Because of the bilayer's impermeability, living organisms can sustain a chemically oxidising internal environment of high complexity in a state of non-equilibrium with the chemically reducing, less complex external environment. The impermeability of the biological membrane to passively diffusing materials also allows cells to sustain and regulate high internal concentrations of thousands of types of often very complex organically synthesised molecules (Allen \& Starr 1982, Alberts et al. 1994, Depwer \& Weber 1996, Voet et al. 1999, Madigan et al. 2003, Williams \& Fraústo Da Silva 2003). Of necessity, cross-membrane substance trafficking (movement) in both prokaryotes (Madigan et al. 2003) and eukaryotes (Alberts et al. 1994, Voet et al. 1999) is governed by proteins dissolved within the membrane. Thus, the diffusion model is inconsistent with contemporary biological understanding. It cannot accurately assess risks posed by pollutants to living organisms, especially those pollutants that are readily sorbed onto organic particles in sediments or suspended in water, and incorporated via ingestion. Prime candidates for such uptake are insecticides, many organic industrial chemicals, and many heavy metals.

The concept of protein-regulated cross-membrane trafficking of substances is well established in the biological sciences, including molecular biology, biochemistry and medicine, but has not previously been applied in ecotoxicology. We here propose that the uptake, internal transport and elimination of all pollutants by living organisms is regulated by proteins dissolved within biological membranes, and by intracellular transport proteins. This 'protein model' must be urgently incorporated into the conceptual framework for ecotoxicological research. While not based on original experimental data, our work does draw upon an extensive literature from biochemistry, molecular and cell biology, genetics, pharmacology, anaethesiology, oncology, physiology, ecology and marine biology, as well as ecotoxicology.

In this paper, we first consider ecotoxicology's diffusion model. Secondly, evidence from other models that might explain cross-membrane transport of molecules is evaluated. Thirdly, the protein-transport mechanism from cell biology is applied to the uptake and elimination of pollutants and their metabolites by living organisms. Finally, we present some of the implications of the protein model and its application for the conduct and validity of ecotoxicological studies, with emphasis on aquatic environments. This paper's primary theme is the fates of organic contaminants, with less emphasis on heavy metals to limit text length. The environmental fates of heavy metal contaminants will be protein-regulated in the same general manner as organic pollutants.

\section{MODELS}

\section{Theory and application of 'diffusion model' in ecotoxicology}

The 'diffusion model', first developed about 20 yr ago by chemists and engineers under the guise of parti- 
tioning coefficients $(K)$, is employed to explain movement and accumulation of pollutants between and within primary storage sites (e.g. air, aquatic sediments, soils, water and living organisms). Accordingly, partitioning is determined entirely abiotically by concentration gradients between storage sites of the contaminant's solutes (see Fig. 1) (e.g. Hawker \& Connell 1985, 1986, 1988a, Connell 1988, Coats et al. 1989, Connell \& Bycroft 1990, Just et al. 1990, De la Torre et al. 1995, Murphy et al. 1995, Karrupiah \& Gupta 1996, Hamer et al. 1999, Mortimer et al. 1999, Chu \& Chan 2000, Anderson et al. 2001, Hendriks et al. 2001, Nipper et al. 2002, Fent 2003). While the diffusion model is based on principles of physical chemistry that have been validated for abiotic environments, it is of limited value when applied to biota because it does not allow for the biological membrane's ability to isolate and regulate substance uptake, nor its capacity to actively export substances, including many toxins (see later subsection 'Why diffusion is not the process ...'). Partitioning coefficients are favoured because they are simple, quick, and inexpensive to measure, and use generalised equations to extrapolate the risks posed by thousands of toxic substances to millions of species (Hendriks et al. 2001).

Under the diffusion model, the focus in ecotoxicological studies is on concentrations of pollutant solutes in the water column and substrate pore waters in aquatic and soils (e.g. Hawker \& Connell 1985, 1986, 1988a,b, Connell et al. 1988a,b, Markwell et al. 1989, Connell 1990, Connell \& Bycroft 1990, Di Toro et al. 1991, Murphy et al. 1995, Skoglund et al. 1996, Van Beelan \& Fleuren-Kemila 1997, Hamer et al. 1999, Camusso et al. 2000, Collavini et al. 2000, Peso-Aguiar et al. 2000, Berglund et al. 2001, Nipper et al. 2002). For aquatic ecosystems, it has been stated that: 'With the exception of a limited number of highly lipophilic pollutants, waterborn exposure is considered the most relevant exposure route for aquatic organisms ... some consider ... only the dissolved fraction is bioavailable for pelagic organisms' (Carbonell et al. 2000, p. 107), and that '... pore water provides a direct measure of contaminant exposure to aquatic organisms because it incorporates the physical and chemical parameters that affect bioavailability' (Nipper 2000).

Thus, concentrations of sediment and soil-bound contaminants are not used as direct indicators of pollution threats, despite the knowledge that (1) $>99.99 \%$ of highly lipophilic pollutants may be associated with sediments in aquatic ecosystems (e.g. Meador et al. 1995, Hamer et al. 1999, Chu \& Chan 2000, Nipper 2000, Anderson et al. 2001, Burd 2002, Maskaoui 2002, Smith \& Pritchard 2002, Fent 2003, Van der Oost et al. 2003), (2) sediments, therefore, are major repositories for organic pollutants (e.g. Tagatz et al. 1987, Meador et al. 1995, Hamer et al. 1999, Chu \& Chan 2000, Nascimento et al. 2000, Nipper 2000, PesoAguiar et al. 2000, Anderson et al. et al. 2001, Wong et al. 2001, Burd 2002, Lahr et al. 2002, Maskaoui 2002, Smith \& Pritchard 2002, Vijver et al. 2002, Fent 2003, Van der Oost et al. 2003), (3) sediments also may store high concentrations of heavy metals (e.g. Birch et al. 2000, Tilquin et al. 2000, Burton et al. 2001, Ellis et al. 2001, Burd 2002, Zabetoglou et al. 2002), and (4) that soils are major storage sites in terrestrial ecosystems (e.g. Chu \& Chan 2000, Hund-Rinke \& Kordel 2003).

Many sediment-bound organic pollutants, notably persistent organic pollutants (POPs) (e.g. Hawker \& Connell 1986, Connell 1988, Zhou et al. 2000, Guruge \& Tanabe 2001), and many heavy metals, are also highly stable in the environment (e.g. Lawrence \& Mason 2001, Doyle et al. 2003, Peltier et al. 2003). Such longevity enhances a contaminant's bioconcentration and bioaccumulation in biota (e.g. Hawker \& Connell 1986, Connell 1988, Weis \& Weis 1992, Munoz et al. 1996, Peters et al. 1999, Ruus et al. 1999, Dang Duc Nhan et al. 2001, Fisk et al. 2001, Lawrence \& Mason 2001, Senthilkumar et al. 2001, Scheifler et al. 2002a,b, Weltje et al. 2002, Hursthouse et al. 2003, Van der Oost et al. 2003). Currently, bioconcentration and passage of pollutants through food webs is interpreted as solute-phase diffusional uptake in all trophic-level interactions (e.g. Schramm et al. 1998, Peters et al. 1999, Ruus et al. 1999, Carbonell et al. 2000, Fisk et al. 2001, Weltje et al. 2002). Biomagnification along the food chain is thought to occur via transfer of solute pollutants from food within the intestinal lumen of animals (e.g. Fisk et al. 2001, Fent 2003, Van der Oost et al. 2003). This ignores the fate of pollutants bound to food macromolecules, which are actively transported across the membrane of gut-wall epithelial cells.

\section{The 3-phase model}

In tests for lipophilic pollutants in aquatic ecosystems, the diffusion model is represented by the '3-phase model' (e.g. Hawker \& Connell 1985, 1986, 1988a,b, Baughman \& Perenich 1988, Markwell et al. 1989, Just et al. 1990, De la Torre et al. 1995, Karrupiah \& Gupta 1996, Hamer et al. 1999, Mitra \& Dickhut 1999, Chu \& Chan 2000, Berglund et al. 2001, Nipper et al. 2002, Skrabal \& Terry 2002, Williamson et al. 2002) (Fig. 1). Protocols for its application specify 3 locations for pollutants - sediments, water and lipids (i.e. living organisms) (Hawker \& Connell 1986, 1988b, Markwell et al. 1989, De la Torre et al. 1995, Mitra \& Dickhut 1999, Nipper et al. 2002, Williamson et al. 2002). Although it was not originally intended for such, the 3-phase model has been extended to studies of pollutants in 


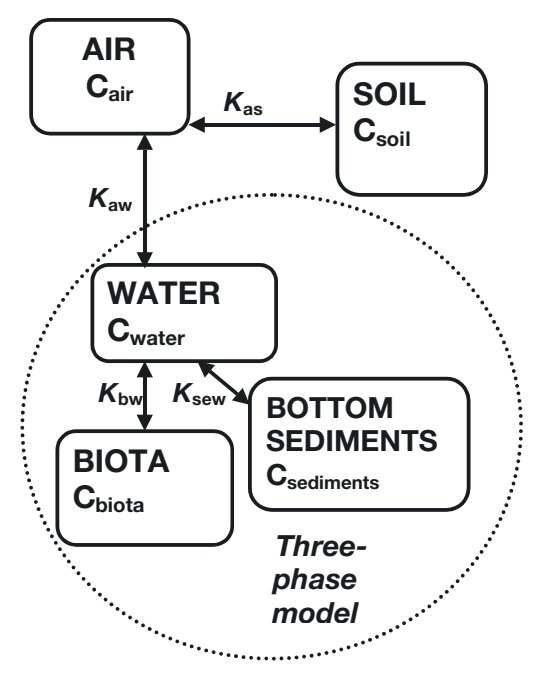

Fig. 1. 'Diffusion model' incorporating '3-phase model' for a toxic chemical in a river system. C: concentrations at different sites for air (a), soil (s), water (w), biota (b) and sediments (se); $K$ : partitioning coefficient between sites (after Connell \& Bycroft 1990, p. 313). Note there is no direct connection between contaminants in sediments and biota

terrestrial ecosystems (e.g. Stenerson 1992, Trapp et al. 2001, Hund-Rinke \& Kordel 2003, Scheifler et al. 2003) and to include heavy metals (e.g. Collavini et al. 2000, Lahr et al. 2002, Datry et al. 2003, Scheifler et al. 2003) and other ionic pollutants (e.g. Zabetoglou et al. 2002). Under the 3-phase model, concentrations of lipophilic pollutants in tissues depend on abiotic partitioning coefficients $\left(K_{\mathrm{ow}}\right)$ between the solute (w) and lipid phase, which in laboratory tests is often represented by octanol (o) (e.g. Hawker \& Connell 1988a,b, Coates et al. 1985, Chu \& Chan 2000). Thus, global concern about 'water pollution' levels is a reflection of the 'solute is the active phase' concept of ecotoxicology's 3-phase model, and downplays the potentially great direct environmental impact of sediment-bound contaminants. Similarly, in terrestrial ecosystems, application of the 3-phase model to studies of pollutants has led to substantial concern about contamination of ground-water and, with less immediate concern, about the risks of soil-bound contaminants. Other partitioning coefficients also may be employed, notably a soil/sediment partitioning coefficient and a water-solubility coefficient (Periera et al. 1988). All are based on the principle of passive diffusion.

\section{Abiotic partitioning coefficient $\left(K_{\mathrm{ow}}\right)$ tests}

Application of the diffusion model includes the use of ex vivo tests to determine partitioning coefficients. In these, living organisms are replaced by a functional substitute (usually octanol), sometimes with an artificial semipermeable membrane device (SPMD) to partition water and the test lipid or lipid substitute (e.g. Di Toro et al. 1990, 1995, Carbonell et al. 2000, Williamson et al. 2002). The SPMD consists of a polymeric membrane that encloses a model lipid, and acts as a passive integrative sampler for determining the aqueous concentration of hydrophobic contaminants (Williamson et al. 2002).

Some ecotoxicological studies involving highly lipophilic pollutants have shown that $K_{\text {ow }}$ approximates the measured water: living organism partitioning for highly lipophilic compounds (e.g. Hawker \& Connell 1988a, Periera et al. 1988, Connell et al. 1993, Mitra \& Dickhut 1999, Mirtagotri 2002). Such apparent affirmation of the 3-phase model has resulted in its uncritical acceptance. In contrast, many studies have also found that partitioning coefficients do not explain experimental outcomes, even for highly lipophilic materials (e.g. Maskaoui 2002, Zabetoglou et al. 2002) and that $K_{\text {ow }}$ does not explain observed partitioning based on tissue loads and water concentrations (Moriarty 1988, Halling-Sørensen et al. 2000, Maskaoui, 2002, Fent 2003) and, predictably, that tissue loads are often more useful for assessing contamination than $K_{\text {ow }}$ (Moriarty 1988). Agreement between tissue pollutant loads and a $K_{\text {ow }}$ for some chemicals simply demonstrates that highly lipophilic chemicals are readily and preferentially deposited or sequestered in adipose tissues of the test organisms via transport proteins. This will be especially true if an organism lacks the transport proteins necessary for elimination of a particular lipophilic pollutant. Even more questionable, given the biochemical and physiological variability between living organisms, has been the practice of extrapolating the findings from studies of $K_{\text {ow }}$ on one organism to other species (Hendriks et al. 2001).

Concern that the 3-phase model under-represents the complexity of aquatic pollutant chemistry led to application of the 'critical micelle concentration' concept for assessing environmental fates of lipophilic pollutants (Di Toro et al. 1990, Park et al. 2002). This concept is highly applicable to understanding encapsulation, concentration and transport of pollutants in aqueous environments (see later subsection 'Delivery of pollutants to receptor proteins'), but was not extended to the delivery and uptake of pollutants across biological membranes. Why diffusion is not the process - function
of biological membrane

For a living biological organism to consist of cells enclosed by semipermeable membranes is contrary to 


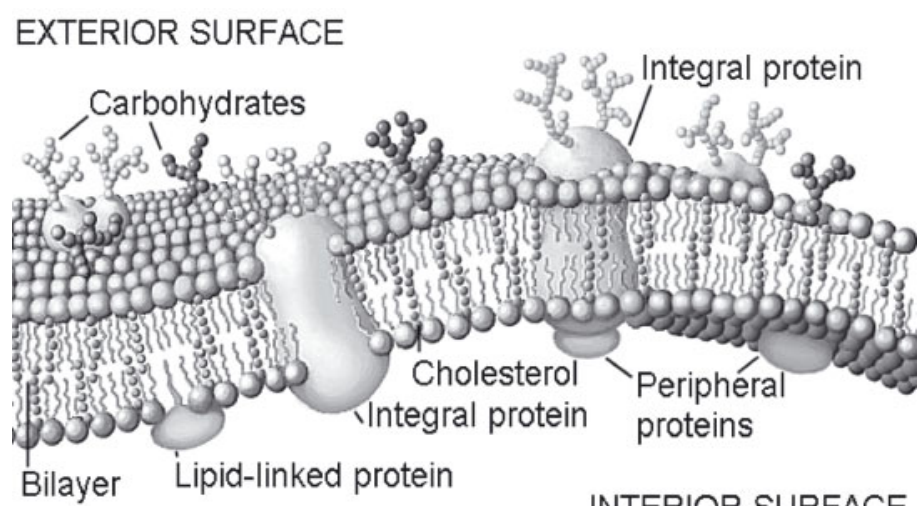

Fig. 2. Biological membrane showing proteins embedded in phospholipid bilayer. Integral proteins includes transport proteins. Lipidlinked proteins mediate protein-protein interactions or modify the functions of other proteins with which they associate. (Illustration Sally Elmer adapted from Alberts et al. 1994 and Voet et al. 1999)

its intrinsic need to maintain specific internal homeostasis (Depwer \& Weber 1996). The biological membrane is an amphiphilic (i.e. simultaneously hydrophilic and hydrophobic) asymmetrical bilayer of phospholipids, about $\sim 60 \AA$ thick, containing $\sim 5 \times 10^{6}$ lipid molecules $\mu \mathrm{m}^{-2}$ (Alberts et al. 1994, Voet et al. 1999). Within the bilayer are regulatory proteins and cholesterol molecules (membranes may have as many cholesterol units as phospholipids) that enhance the bilayer's impermeability (Alberts et al. 1994) (Fig. 2). The membrane's outer surface bristles with carbohydrates, whose functions are still being unravelled. In eukaryotes the membrane is assembled in the endoplasmic reticulum (ER), where basic membrane asymmetry is generated according to each cell's needs (Alberts et al. 1994, Voet et al. 1999, Camus et al. 2000).

The 'formidable' impermeability (Alberts et al. 1994) of the biological membrane is conferred by the structure of the membrane's bilayer. Because they are charged (hydrophilic), phospholipid 'heads' interact readily with water, forming external and internal membrane surfaces that are highly lipophobic and, therefore, powerful barriers to diffusing solutes of nonpolar (lipophilic) substances. In addition, diffusion of non-polar materials towards the membrane is inhibited by a zone of still water up to $2 \mathrm{~nm}$ thick, covering both membrane surfaces (Alberts et al. 1994). Phospholipid 'tails', in contrast, are non-polar and form the double inner lipophilic zone that is a powerful hydrophobic barrier to diffusing solutes. The impermeability of the biological membrane is such that even protons $\left(\mathrm{H}^{+}\right)$ cannot diffuse across it (Madigan et al. 2003). Substances cross the living biological membrane only through the activity of proteins embedded within the membrane.

\section{Alternative mechanisms for cross-membrane transport}

Given the impermeability of the biological membrane, only 2 mechanisms currently known in molecular biology can be invoked to explain cross-membrane trafficking of pollutants by living organisms, i.e. 'flip-flops' (for complex molecules that may embed in the lipid bilayer of the membrane) and protein transport.

The flip-flop has been proposed as the mechanism by which phospholipids transfer from one side of the biological membrane to the other (Alberts et al. 1994). A study of oleic acid (an essential lipid-soluble fatty acid) indicated that oleic acid binds with the lipid domain of the membrane and is transferred across the membrane within 5 s via a flip-flop (Kamp et al. 2002). Because the study also showed that oleic acid had a partitioning coefficient similar to that in synthetic phospholipid bilayers, the flip-flop has been considered as a possible explanation of pollutant trafficking across the membrane. In synthetic lipid bilayers, spontaneous flip-flop occurrence is $<1 \mathrm{mo}^{-1}$ molecule ${ }^{-1}$, leading to the general consensus that spontaneous flip-flops are extremely rare (Alberts et al. 1994, Voet et al. 1999). Instead, enzymatic proteins (flipases) catalyse the transfer of essential materials, including fatty acids, across the membrane. Flipases are highly substrate-specific and it is most unlikely that any would transfer pollutants. They are also active mainly within the cell's ER, which should not be readily exposed to toxins originating outside the cell. Therefore, flip-flops, which may allow very slow rates of abiotic uptake of molecular units that successfully embed in the bilayer, cannot explain the high rates of cross-membrane trafficking of pollutants (e.g. 'knockdown' insecticides).

\section{‘Protein model' for pollutant transport}

A 'protein model', whereby cross-membrane trafficking of substances is mediated by an array of specific proteins embedded in the biological membrane, appears to be the only viable explanation available now for uptake and elimination of pollutants by living organelles, cells, tissues and organisms. Identification of the regulatory proteins is revolutionising cell-membrane biology. Quite recent text books (e.g. Voet et al. 1999) state that water diffuses across the cell membrane; however, aquaporins and an increasing number of other proteins have been identified as regulators of cross-membrane water transport (Chaumont et al. 2001, Garcia et al. 2001, Sansom \& Law 2001, Zeuthen 
et al. 2001, Konzo et al. 2003, Madigan et al. 2003). Protein transporters also have been found for other small molecular units, including $\mathrm{NH}_{3}$ (Hu \& Wu 2001) and NO (Closs et al. 2000, Stevens et al. 2000). Internal transport proteins also are involved in internal movements of substances, including lipidic molecules (e.g. $\mathrm{O}_{2}$ by haeme-proteins) (Van De Graaff \& Fox 1992, Alberts et al. 1994), whose insolubility in water results in limited amounts being available via passive diffusion.

\section{Cell protein diversity}

About $10^{9}$ proteins of $\sim 10^{4}$ types occur in a typical mammal cell (Alberts et al. 1994). Other eukaryotic cells probably have comparable numbers and kinds of proteins. Some proteins are structural, many are functional (e.g. catalysts and transporters). Designation of locations and concentrations of transport proteins in eukaryotes (Alberts et al. 1994) is a factor in specialisation of organelles, cells, tissues, organs, individuals, and even species. In mammalian nerve-cell myelin sheaths, whose primary function is electrical insulation, less than $25 \%$ of the membrane mass is protein, whereas proteins form about $75 \%$ of membrane biomass in membranes whose function is energy transduction (e.g. mitochondria) (Alberts et al. 1994). Proteins may collaborate in trafficking regulation. Pores in the membrane of eukaryotic cell nuclei, which govern movement of molecules into and out of the nucleus, contain up to 1000 proteins of 50 to 100 kinds (Voet et al. 1999). Proteins are synthesised in the cell's ER and, like membrane lipids, once in place membrane proteins do not flip-flop across the bilayer (Alberts et al. 1994).

Transport proteins have been grouped into a number of families based on fundamental chemical structure. A few of these protein families seem to have arisen recently in evolutionary time (Ahearn et al. 2001, Paden et al. 2001), but genome analyses show that most proteins appear to belong to a limited number of archaic family groupings that have diversified into an array of kinds (Quintero \& Blatt 1997, Paden et al. 2001, Petit et al. 2001, Konzo et al. 2003). The YCF 1 transport protein, which eliminates $\mathrm{Cd}^{2+}$ from yeasts, is very similar to a protein that eliminates $\mathrm{Cd}^{2+}$ from insect cells (Ren et al. 2000). Therefore, studies of protein functions in one organism type (e.g. yeasts or fishes) may be useful in understanding similar functions in other types of organisms (e.g. insects, mammals and flowering plants). The development of transport proteins must have been as critical in the evolution of the primordial cell $\sim 3.5$ billion yr ago as formation of the biological membrane and the assembly of nucleic acids.
How transport proteins mediate
cross-membrane trafficking

Transport proteins function in 2 basic ways, as channels or carriers. Channel proteins form temporary aqueous pores that open and close according to a cell's requirements. Carrier proteins bind to molecular units for transport without chemically transforming them (Madigan et al. 2003), then pass across the lipid bilayer or structurally reconfigure to release the transported substance on the other side of the membrane (Voet et al. 1999). All transport proteins identified so far have been highly substrate-specific. Valinomycin, a bacterial channel protein, accommodates $\mathrm{K}^{+}(\mathrm{r}=1.33 \AA$ ), but not $\mathrm{Na}^{+}(\mathrm{r}=0.95 \AA)$ or $\mathrm{Li}^{+}(\mathrm{r}=0.60 \AA$ ) (Alberts et al. 1994). In Escherichia coli, the OmpF porin (channel protein that carries low molecular weight, ionic substances) forms a weakly positively charged channel, that admits only anions $<600 \AA$, whereas the structurally similar PhoE has a weakly negative changed channel that carries only small cations (Voet et al. 1999). Protein expression in membranes can be determined by environmental conditions. In E. coli, the osmolarity of the environment determines whether the OmpF or the OmpC is synthesised in the bacterium's outer membrane (Madigan et al. 2003).

\section{Channel proteins}

Channel proteins form aqueous pores extending across the membrane bilayer. These function in a 'gated' (open-closed) manner (Alberts et al. 1994) (Fig. 3). When open, channel proteins allow 'facilitated diffusion' of materials down concentration or electro-

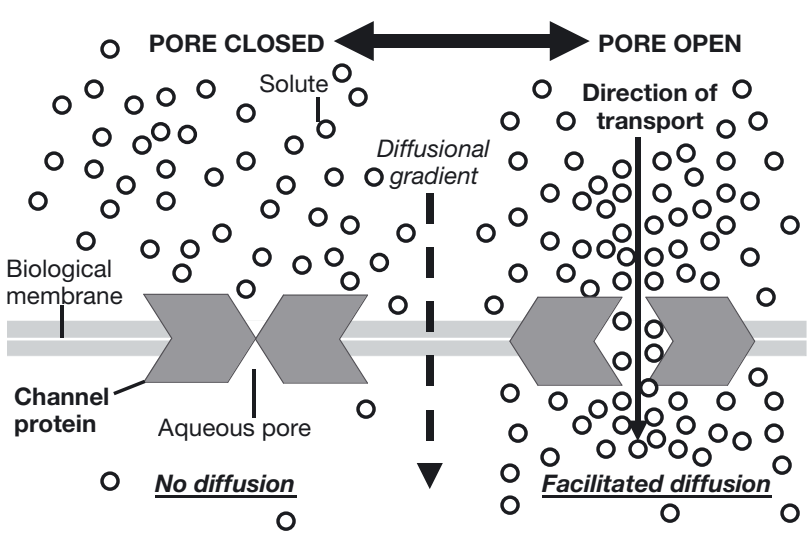

Fig. 3. Diagrammatic representation of channel protein functioning. Protein operates in a gated (open-closed) manner according to a cell's or organelle's needs. Open proteins allow solutes to move along their concentration or electrochemical gradients; such proteins transport only small ions. (Illustration S. Quinnell adapted from Alberts et al. 1994 and Voet et al. 1999) 
chemical gradients according to a cell's needs, closing once those needs are met. Evidence suggests that only small ions are transported in this manner (e.g. $\mathrm{H}_{2} \mathrm{O}$, $\mathrm{Cl}^{-}, \mathrm{K}^{+}, \mathrm{Na}^{+}$) (Alberts et al. 1994) and that channel proteins are highly selective of substances for transport. Solutes as small as $\mathrm{Fe}^{2+}$ and $\mathrm{Fe}^{3+}$ may employ carrier proteins. Therefore, channel proteins may not be involved in cross-membrane trafficking of pollutants except, perhaps, of some very small ionic units (e.g. $\mathrm{NH}_{4}^{+}$).

Subtle changes to protein trafficking can have profound metabolic effects (Stewart at al. 2000). The antibacterial drug Gramacidin A is a channel protein of 15 amino acid residues. When inserted into a bacterium's membrane, Gramacidin A allows up to $2 \times 10^{7}$ monovalent cations $\mathrm{s}^{-1}$ flow across the membrane, causing a fatal collapse of essential $\mathrm{H}^{+}, \mathrm{Na}^{+}$and $\mathrm{K}^{+}$ concentration gradients between the bacterium and its external environment. Xenobiotics, including many biocides, often are toxic because they disrupt channel protein functions. Lyngbya spp. (Cyanobacteria) produce a toxin that interferes with the functioning of an $\mathrm{Na}^{+}$channel protein. Puffer fish poison (tetrodotoxin) acts on proteins that transport $\mathrm{Ca}^{2+}$ ( $\mathrm{Li}$ et al. 2001). Ivermectin, a lipophilic antiparasitic drug, used against helminth parasites, kills by causing disruption of channel proteins that govern trans-membrane trafficking of $\mathrm{Cl}^{-}$ions (Slimko \& Lester 2003). Insect resistance to pyrethroids and DDT involves mutations in genes that code for $\mathrm{Na}^{+}$transport proteins (Liu et al. 2000, Ranson et al. 2000). In the fungus gnat Drosophila melanogaster, resistance to the insecticides dieldrin and fiprinol involves changes to $\mathrm{Cl}^{-}$channel proteins and can be invoked by a single-point genetic mutation (FrenchConstant et al. 1993, Housi et al. 1995).

\section{Carrier proteins}

Carrier proteins transport materials by chemically binding the substance to the receptor sites. Small bacterial carrier proteins move substances from one surface to the other by diffusion through the lipid bilayer. Large carrier proteins reconfigure before releasing the transported substance on the opposite side of the biological membrane. When substances are transported against their diffusional or electrochemical gradients, the process is powered by ATP (Alberts et al. 1994) (Fig. 4). Some protein types transport single molecules; others function as coupled transporters with different substances shuttled across the membrane simultaneously, sometimes in the same direction, sometimes in opposite directions. A23187, a protein that transports $\mathrm{Ca}^{2+}$ and $\mathrm{Mg}^{2+}$ into a cell carries $2 \mathrm{H}^{+}$ions out for every divalent cation carried in (Alberts et al. 1994). In the

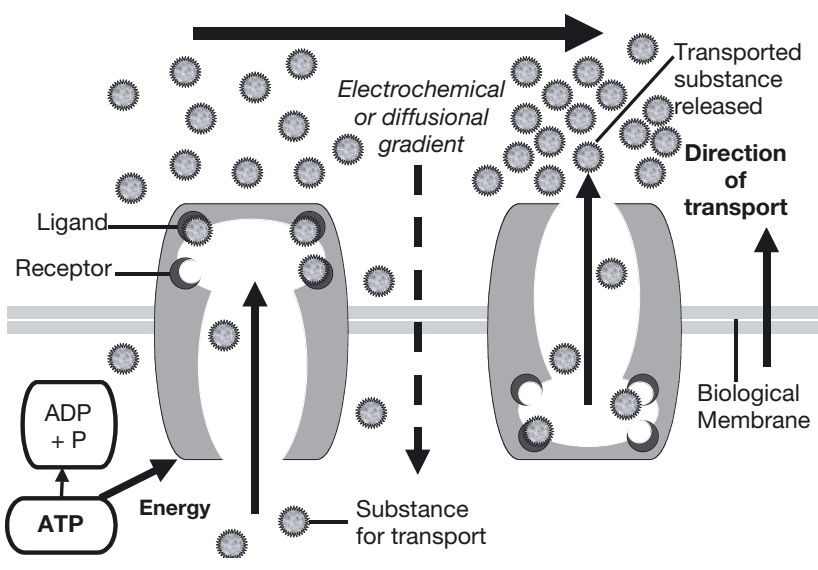

Fig. 4. Diagrammatic representation of carrier protein that utilises ATP to transport a substance against its electrochemical and concentration gradient. (Illustration by S. Quinnell adapted from Alberts et al. 1994 and Voet et al. 1999)

hepatopancreas of the lobster Homarus americanus, $\mathrm{Cl}^{-}$can use 3 coupled transporters $\left(\mathrm{SO}_{4}{ }^{2-}\right.$, oxylate ${ }^{2-}$ and $\mathrm{HCO}_{3}^{-}$) (Gerencser et al. 1995). The flowering plant Catharanthus roseus absorbs the herbicide glyphosate through an Fe transporter, which is stimulated into action by $\mathrm{Ca}^{2+}$ (Tilquin et al. 2000). Transport of $\mathrm{NO}$, which is synthesised from L-arginine, is governed by the proteins that transport L-arginine (Closs et al. 2000, Stevens et al. 2000). Transport proteins can be identified through the use of protein inhibitors (Gerencser et al. 1995), a technique common in molecular biology and biochemistry, and one that should be applied in ecotoxicology.

Why pollutants may be imported

From the foregoing it is clear that pollutants can only cross the impermeable biological membrane through protein-regulated admission. Here, 2 adventitious mechanisms are proposed.

Similarity. This mechanism operates when a pollutant's chemical structure is highly similar to that of an essential molecule, allowing the pollutant to form a ligand with carrier proteins. An example is the intracellular transport of $\mathrm{CO}$ in vertebrates by its attachment to haemoglobin at the site that normally binds $\mathrm{O}_{2}$. Because the haeme-CO bond is 210 times stronger than the haeme- $\mathrm{O}_{2}$ bond, $\mathrm{CO}$ tends to displace $\mathrm{O}_{2}$, causing CO poisoning (Van De Graaff \& Fox 1992). Similarly, oestrogen mimicking substances (e.g. many biocides, phthalate esters) may act by binding onto oestrogen receptor proteins.

Concealment. This allows pollutants to cross the biological membrane undetected because they are bound 
to large metabolically essential units (Patton 1981, Kanda et al. 1990). Examples include pollutants bound to an organic food molecule (e.g. a fatty acid or polypeptide) (Kanda et al. 1990), or to a molecular complex (e.g. micelles, liposomes and lipopolysaccharides) that is imported. Concealment is likely to be the route by which most pollutants enter metazoans, including those pollutants that are highly insoluble in water (e.g. many organic biocides and industrially synthesised chemicals). Such uptake probably occurs on any external epithelial cell surface. The movement of concealed substances between a cell and its environment was proposed in medicine more than $20 \mathrm{yr}$ ago (e.g. Patton 1981, Kanda et al. 1990), but has received virtually no attention in ecotoxicology.

\section{Pollutant elimination}

Ecotoxicology's diffusion model assumes that pollutant elimination also occurs by passive diffusion (e.g. Hawker \& Connell 1985, 1988a,b, Connell 1988, Stenerson 1992, Randall et al. 1998). However, an array of proteins capable of excreting many types of xenobiotics, including lipophilic substances, have been identified. The actions of some of these underlie major medical problems, including antibiotic and multi-drug resistance (MDR), as well as biocide resistance in pest and weed species (Alberts et al. 1994, Schäfer et al. 1996, Al-Awqati 1999, Closs et al. 2000, Stevens et al. 2000, Thumser \& Storch 2000, Ueda \& Matsuk 2000, Chaumont et al. 2001, Garcia et al. 2001, Hu \& Wu 2001, Marples 2001, Nejsum et al. 2001, Sansom \& Law 2001, Zeuthen et al. 2001, Raggers et al. 2002, Madigan et al. 2003). Ivermectin, a lipophilic drug toxic to helminths, is tolerated by mammals if their cells can rapidly synthesise the appropriate proteins to eliminate the drug (Schinkel et al. 1994, Umbenhauer et al. 1997, Smith \& Pritchard 2002). The ubiquitous large ABC superfamily of exporters is well known (van Veen et al. 2000). Increased expression of P-glycoproteins (an ABC subgroup) in insects has been linked to insecticide resistance (Retnakaren et al. 2001), with activity levels of P-glycoprotein-mediated processes related to levels of environmental pollution (Smital et al. 2000).

Detection of a xenobiotic in cells triggers expression of exporter proteins, provided the appropriate genetic code for their expression exists. Possession of preexisting genetic codes indicates exposure to similar cytotoxins in an ancestral cell/organism and conservation of the genetic response through generations. Pollutants which pose the lowest threat to life probably will belong to classes of molecules encountered frequently during evolutionary history (e.g. hydrocarbons and some heavy metals), allowing opportunity for the evolution of genetic codes to express the appropriate export proteins. The most toxic pollutants should be those that are environmentally novel or rare in biologically available forms as well as industrially synthesised chemicals (e.g. organochlorides, PCBs, dioxin and some heavy metals).

The diffusion model cannot account for observed high rates of cross-membrane trafficking, such as very high metabolic flux rates of virtually insoluble longchain fatty acids into tissues (Thumser \& Storch 2000), nor can it explain disparities in xenobiotic uptake and elimination between organisms within single species, such as why mice lacking the gene for expression of mdr1a P-glycoprotein accumulate 100 times more Ivermectin (a lipophilic drug) in their brains than mice with the appropriate gene (Schinkel et al. 1994). The diffusion model also cannot explain the very rapid impact on living organisms of highly lipophilic insecticides, whose solute concentrations and, therefore, rates of aqueous diffusion are very slow. The functioning of transport proteins provides a credible explanation of pollutant uptake and elimination by cells, organelles and organisms, although the process may be an indirect consequence of the proteins' intended biological functions (see later subsection 'Delivery of pollutants to receptor proteins').

\section{Endocytosis-transcytosis-exocytosis cycle}

In eukaryotes, transport proteins are located in pits at sites of need (domains) within cells, with sometimes thousands of transporters for a specific chemical often concentrated in a single pit (Alberts et al. 1994). Formation of ligands between the substance to be transported and a critical number of transport proteins in a pit triggers endocytosis, the most conspicuous material-uptake process in the cell. Endocytosis consists of 2 primary forms, phagocytosis and pinocytosis, although intermediate processes are known. Phagocytosis is limited to amoeboid cells, which use it to incorporate large particles and whole microorganisms (Roitt 1994, Lodish et al. 2000), and is apparently not a significant pollution uptake route (Kujawinski et al. 2000). Pinocytosis occurs in virtually every type of eukaryotic cell (Alberts et al. 1994), and is thus the dominant form of endocytosis. In macrophages the entire biological membrane's surface area goes through pinocytotic invagination every $30 \mathrm{~min}$ and thus an external substance can be rapidly transported inside the cell (Alberts et al. 1994). The rate of biological membrane in-pocketing is determined by the concentration of the substance for transport in the cell's external environment and the density of carrier proteins on the cell surface (Lodish et al. 2000). Pinocytosis is presumably 
how pollutants concealed on ingested material are incorporated into eukaryotic cells.

The continual loss of biological membrane through endocytosis is offset by exocytosis, by which transport proteins eliminate materials from cells (e.g. wastes, signalling-molecules and xenobiotics). Exocytosis occurs at the same rate as endocytosis, ensuring that the total surface area of a cell or organelle is maintained (Alberts et al. 1994). Specific exocytotic protein transporters are located at different sites on the biological membrane according to an organelle's, cell's or tissue's function (Alberts et al. 1994). This allows substances to be excreted from individual cells (Sun et al. 2000) to specific extracellular locations (skin, blood, lymph, nerve synapses, gut lumen, etc.), or excreted (by liver, pancreas, nephridia gills and skin) (Cunningham 1992).

'Transcytosis' here refers to the processing of pollutants within a cell. Besides the process of intracellular digestion (hydrolysis), the nucleus issues instructions for protein synthesis, the Golgi apparatus synthesises

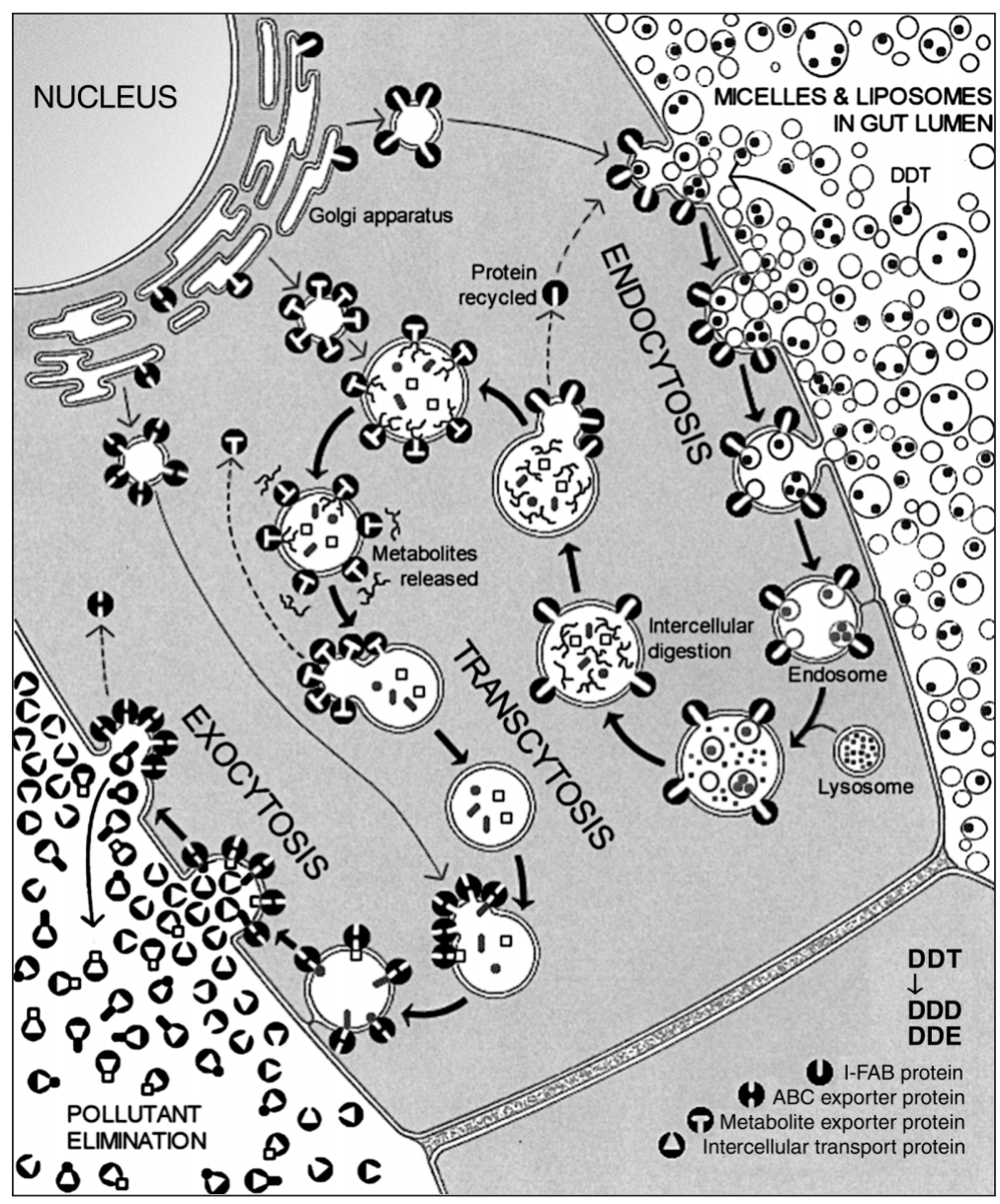

Fig. 5. Protein model of pollutant uptake and elimination. For details see text. (Illustration by Sally Elmer \& S. Quinnell) proteins, and the ER delivers proteins to where they are needed. Most transcytosis pathways are less well known than transport processes at external cell membranes, but have been shown to involve transport proteins; also sequestering of toxins may occur at the organelle level (Rajagopal \& Simon 2003). Breakdowns in transcytosis may be reflected by alterations to physiological processes (Wong et al. 2001).

The endocytosis-transcytosis-exocytosis cycle, as applied to pollutant uptake and elimination from eukaryotic cells (the protein model), is represented in Fig. 5, which postulates the fate of DDT ingested as a food contaminant entering through a simplified gutwall epithelial cell. Because of its high lipophilicity, DDT is assumed to have attached to intestinal liposomes and micelles of fatty acids (see following subsection), although any lipidic molecules may act as DDT carriers. The process of endocytosis presented here is based on the well-known cholesterol uptake pathway (Alberts et al. 1994, Voet et al. 1999). Carrier proteins responsible for endocytosis cluster in pits on the cell's surface. Endocytosis is activated when sufficient micelles and liposomes in the pit have formed ligands with the substance for transport (Sue et al. 1993, Billingsley \& Lahne 1996, Voet et al. 1999). The pit seals off to form an endosome, and commences the process of transcytosis (Alberts et al. 1994). The newly formed endosome migrates inwards and fuses with a lysosome (a sack of hydrolysing enzymes) (Alberts et al. 1994), allowing intracellular digestion to decompose the micelles, liposomes and associated DDT cargo, releasing fatty acid metabolites and metabolites from the decomposition of DDT (e.g. DDE, DDD). All metabolites are then sorted and exported by the appropriate proteins in the vesicle's membrane. Non-hydrolysed DDT, as well as DDE and $\mathrm{DDD}$, will be sequestered within the cell if export proteins are not available for their elimination. However, in this model, we show pollutants being eliminated by an $\mathrm{ABC}$ export protein. These eliminated pollutants are transported by proteins within plasma to sites of metabolism (e.g. liver), elimination (e.g. kidney, gills, skin, intestine) or sequestration (e.g. liver, lungs, gills, kidneys). They may also be incorporated into internal micelles and liposomes within the circulatory system (not shown) and thence transported to sites of elimination or sequestration. Successful elimination of any pollutant from a cell or 
living organism will depend on the existence of appropriate export proteins. Other biomolecular processes are known to play a role in limiting impacts of pollutants, especially insecticides, by chemically binding to the insecticide, inactivating it, and sequestering it internally (e.g. Kostaropoulos et al. 2001). The function of such sequestering molecules also needs to be examined by ecotoxicology.

\section{Delivery of pollutants to receptor proteins}

It has been argued that pollutant diffusion rates in water will ultimately determine cellular uptake rates because pollutants must first diffuse through the external aqueous environment before reaching an organism's transport proteins. This is not so. In aquatic environments (including interstices of soils), micelles and liposomes form spontaneously from phospholipids, and can encapsulate and deliver high concentrations of both lipophilic and hydrophilic materials (Alberts et al. 1994). Micelles and liposomes are highly abundant within the gut lumen and intercellular body fluids and in intercellular fluids (Alberts et al. 1994). Transmembrane crossing of micelles and liposomes is complex and does not involve simple diffusion (e.g. Di Toro et al. 1991, Park et al. 2002)

Micelles are formed from a single-tailed phospholipid layer, and have external hydrophilic heads that interact readily with water and a hydrophobic/lipophilic inner cavity that excludes water (Alberts et al. 1994), but which readily accommodates lipophilic materials (Cserháti et al. 2002, Park et al. 2002) (Fig. 6). Liposomes consist of bitailed phospholipids arranged into 1 or more bilayers that internally encapsulate solutes, but may carry lipophilic materials attached to their lipidic wall (Alberts et al. 1994, Voet et al. 1999) (Fig. 6). Micelles and liposomes composed of fatty acids are readily transported across the biological membrane by forming ligands with the appropriate proteins (e.g. fatty acid-binding proteins: Sue et al. 1993, Billingsley \& Lane 1996, Kaufman et al. 2001).

In animals with alimentary tracts, emulsifiers (e.g. bile salts) and dietary fats form intestinal liposomes and micelles (Alberts et al. 1994), which become primary holding vehicles for suspended food. Peristaltic churning of the gut's contents provides opportunities for suspended liposomes and micelles to make contact with appropriate transport proteins (e.g. intestinal fatty acid-binding proteins) in external epithelial cells of the gut wall. This allows uptake of the micelles and liposomes with their cargo (i.e. high concentrations of food molecules) (Sue et al. 1993, Billingsley \& Lane 1996). Liposomes are used to carry and deliver soluble and lipophilic drugs (Sue et al. 1993, Alberts et al. 1994).
Pollutants bound to micelles and liposomes associated with sediments and soils, as well as those formed in the gut during extracellular digestion of food, probably represent the primary pathway for major dietary uptake of pollutants by deposit-feeding and soilingesting organisms. Contaminated micelles and liposomes also pose a threat to infaunal suspensionfeeding aquatic organisms, but these are probably exposed to much lower pollutant concentrations than deposit-feeders (see below).

Because micelles and liposomes occur throughout aquatic environments and in soils (Di Toro et al. 1990), they may deliver lipophilic pollutants to other external epithelial cells such as the skin and respiratory surfaces. Solute pollutants as well as lipophilic pollutants (e.g. many hormone-mimicking contaminants) may be encapsulated within naturally occurring liposomes and micelles. It needs to be established if micelles and liposomes encapsulate both lipophilic and hydrophilic pollutants, as this will be crucial to understanding the uptake of organic pollutants and probably heavy metals.

Deposit-feeding infauna also appear to be more vulnerable to pollutants than suspension-feeders because their diet incorporates much larger quantities of bacteria and their exopolymers (Hoskins et al. 2003). Detritus, especially plant matter, is a principal nutrient and energy input into estuarine ecosystems (Odum 1971, Hutchings \& Saenger 1987), much of it settling onto sediments (Zabetoglou et al. 2002). However plant matter, especially cell-wall carbohydrates, is not readily accessed by heterotrophs until it has been decomposed by bacteria and fungi. Up to $6.5 \times 10^{9}$ bacteria $\mathrm{ml}^{-1}$

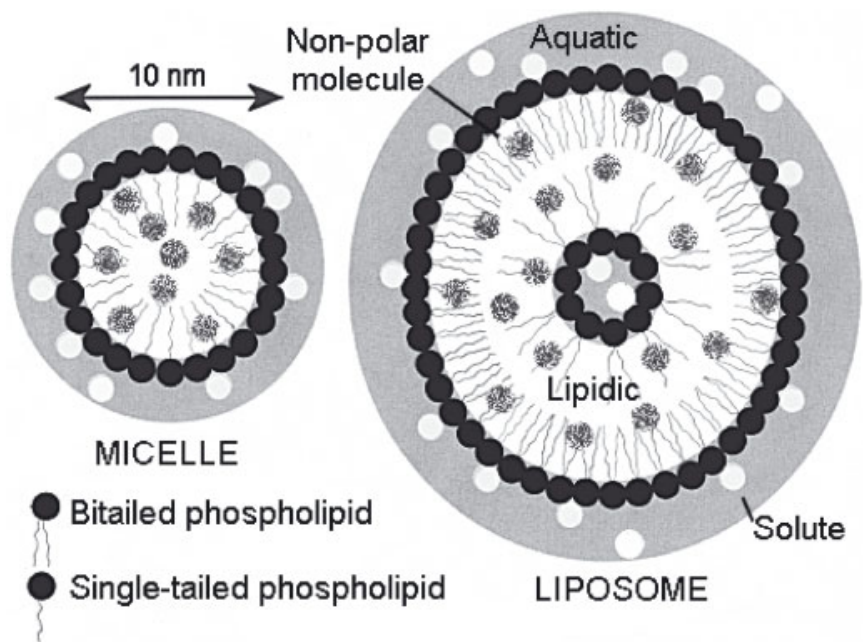

Fig. 6. Micelle and liposome composed of phospholipids showing how their structures confer ability to contain and transport solutes and non-polar lipophilic molecules in aqueous environments. (Illustration S. Quinnell adapted from Alberts et al. 1994 and Voet et al. 1999) 
were reported in sediments from Australian estuaries (Hutchings \& Saenger 1987). These bacteria form extensive external lipidic biofilms of exopolymers (e.g. lipopolysaccharides of Gram-negative bacteria) (Hoskins et al. 2003, Madigan et al. 2003), which offer binding sites to an array of pollutants, especially organic chemicals. Nutrients released by bacterial and fungal detritus decomposition adsorb onto sediment particles, providing nourishment for larger microorganisms (Fenchel 1970, Madigan et al. 2003). These microorganisms, fungi and bacteria are the primary food of deposit-feeders (Lillebø et al. 1999, Wolff et al. 2000).

Suspension-feeders collect food from the water column (Gili \& Coma 1998, Turner \& Millward 2002), where microbial population densities are usually lower than in sediments (Madigan et al. 2003). Thus, the primary food of many suspension-feeders is eukaryotic organisms, such as eggs and plankton, although suspension-feeders may also collect microbes (Gili \& Coma 1998). Sedimentation/resuspension undoubtedly cycles particle-sorbed pollutants between the sediments and water column, but the concentrations of most pollutants are much higher in sediments than in associated water (e.g. Tagatz et al. 1987, Hamer et al. 1999, Fent 2003, Van der Oost et al. 2003). Thus, deposit-feeders are more exposed than suspensionfeeders to most contaminants.

Research in ecotoxicology must begin to include studies of protein-mediated cross-membrane uptake, internal transport and elimination of pollutants, and consideration of the roles micelles and liposomes play in pollutant delivery. Major changes in the monitoring for pollutants in the environment are required urgently, so that we can more realistically assess the actual impact of pollutants on living organisms and ecosystems.

\section{CONCLUSION}

The movement of molecules into and out of organelles, cells, tissues and entire organisms is a protein-governed mechanism in both prokaryotes and eukaryotes. Such regulation is essential because all cells are contained within the impermeable biological membrane. Protein-mediated cross-membrane trafficking takes a number of forms, including facilitated diffusion (channel proteins), active transport (carrier proteins) and, in eukaryotes, endocytosis (phagocytosis and pinocytosis), transcytosis and exocytosis. Intracellular and probably intercellular transport also may be mediated by proteins. Transport proteins may act in isolation, cluster in pits or form complexes of many types. They also are located specifically in cells according to their function.
This paper has concentrated on pollutant uptake from the gut lumen of higher animals. However, any epithelial cell (e.g. skin, lungs and gill membranes), may be an uptake site, especially in aquatic ecosystems where liposomes and micelles are abundant in the eternal environment. Plants possess similar regulatory mechanisms on cell walls and membranes (Raven et al. 1992). Following uptake, the fate of incorporated pollutants is determined by an organism's physiology, metabolism and the range of proteins it is genetically coded to produce.

In aquatic ecosystems, pollutants bound to macromolecules (e.g. polypeptides, polysaccharides, liposomes, micelles and bacterial exopolymers) pose a much greater threat to living organisms than do the same pollutants in their solute (pore water) phase. Under the 'concealment' hypothesis presented here, solutes may not be available for uptake. Macromolecules tend to associate with detritus, sinking and accumulating within sediments. Therefore, deposit-feeding infauna are highly vulnerable to sediment-sorbed contaminants. The concentrations of most pollutants to which deposit-feeding benthic infaunal organisms will be exposed most often will be determined by the quantity of those substances sequestered in the substrate, and not by their dissolved aqueous component. Similarly, the concentration of pollutants to which either benthic or pelagic suspension-feeding organisms are exposed will be determined by the concentration of the pollutant bound to organic matter, especially molecular complexes that are food for suspension-feeders, and not by water concentrations. Infaunal suspensionfeeders are less vulnerable to pollutants than depositfeeders because they utilise a different food resource. Notably, deposit-feeding organisms ingest large amounts of microbial biofilms, which provide ideal binding sites for pollutants, whereas suspensionfeeders do not.

Within the science of ecotoxicology, ingestion of pollutants sorbed to essential macromolecules is not considered as a pathway by which sediment-sorbed pollutants enter aquatic food webs, nor is the role of micelles and liposomes as transport vehicles emphasised. Both are likely to be critical determinants of pollutant uptake. Therefore, global standards for chemical toxicological testing for contamination of both aquatic sediments and terrestrial soils based on pore water concentrations may be leading to a continual underestimation of the risks posed by many contaminants

The diffusion model in use in ecotoxicology is irreconcilable with biological understanding of how living organisms regulate their internal environment. The only instance in which pollutants may diffuse passively across the biological membrane is if the cell is dead or 
dying. Not surprisingly, it has been noted that it is virtually impossible to predict the fate of xenobiotic substances with simple partitioning models (Van der Oost et al. 2003). The protein model should be applied.

Acknowledgements. Dr. H. Chapman, Dr. D. Crane, Dr. D. Hawker, A. A. Bakar and J. Duhs' constructive comments greatly improved this manuscript. Dr. G. Miller (Envirotest) undertook chemical tests. S. Elmer produced the graphics assisted by C. Foord. E. Hegerl AO, Senators I. MacDonald and R. Hill, Mrs. E. Grace, Mr. W. Swan, the late A. Beasley, and M. A. Pattison assisted in obtaining National Heritage Trust funding for this research, which the Australian Department of Environment and Heritage and the Australian Marine Conservation Association administered. Dr. P. Dale, Griffith University, provided facilities for this study.

\section{LITERATURE CITED}

Ahearn GA, Mandal PK, Mandal A (2001) Biology of the $2 \mathrm{Na}^{+} / 1 \mathrm{H}^{+}$antiporter. J Exp Zool 289:232-244

Al-Awqati Q (1999) One hundred years of membrane permeability: does Overton still rule? Nature Cell Biol 1: E201-202

Alberts B, Bray D, Lewis J, Raff M, Roberts K, Watson JD (1994) Molecular biology of the cell, 3rd edn. Garland, New York

Allen TFH, Starr TB (1982) Hierarchy: perspectives for ecological complexity. University of Chicago Press, Chicago

Anderson BS, Hunt JW, Phillips BM, Fairey Rand 8 others (2001) Sediment quality in Los Angeles Harbour, USA: a triad assessment. Environ Toxicol Chem 20:359-370

Baughman GL, Perenich TA (1988) Fate of dyes in aquatic systems. 1. Solubility and partitioning of some hydrophobic dyes and related compounds. Environ Toxicol Chem 7: 183-199

Berglund O, Larsson P, Ewald L, Okla L (2001) Influences of trophic status on PCB distribution in lake sediments and biota. Environ Pollut 113:119-210

Billingsley PF, Lahne MJ (1996) Structure and ultrastructure of the insect midgut. In: Lehane MJ, Billingsley PF (eds) Biology of the insect midgut. Chapman \& Hall, London

Birch GF, Taylor SE, Matthai M (2000) Small-scale spatial and temporal variance in the concentration of heavy metals in aquatic sediments: a review and some new concepts. Environ Pollut 113:357-372

Burd BJ (2002) Evaluation of mine tailings effects on a benthic marine infaunal community over 29 years. Mar Environ Res 53:481-519

Burd BJ, Macdonald R, Boyd J (2000) Punctuated recovery of sediments and benthic infauna: a 19-year study of tailings deposition in a British Columbia fjord. Mar Environ Res 49:145-175

Burton SM, Rundle SD, Jones MB (2001) The relationship between trace metal contamination and stream meiofauna. Environ Pollut 111:159-167

Campbell B, Monroe R, Mather P, Wallace C (1974a) The estuarine sublittoral macrobenthos of southeastern Queensland: a preliminary survey. University of Queensland, Brisbane

Campbell B, Wallace C, King H (1974b) The sublittoral macrobenthos of the proposed Brisbane Airport extension area. Brisbane Airport Development Project Environmental Study, Australian Government. Queensland Museum, Brisbane
Campbell B, Wallace C, King H (1974c) A field study of the littoral invertebrate macrofauna from the proposed Brisbane Airport extension area. Brisbane Airport Development Project Environmental Study, Australian Government). Queensland Museum, Brisbane

Camus L, Grøsvik BE, Børseth JF, Jones MB, Depledge MH (2000) Stability of lysosomal and cell membranes in haemocytes of the common mussel (Mytilus edulis): effect of low temperatures. Mar Environ Res 50:325-329

Camusso M, Vignati D, van de Guchte C (2000) Ecotoxicological assessment in the rivers Rhine (The Netherlands) and Po (Italy). Aquat Ecosyst Health Manag 3:335-345

Carbonell G, Ramos C, Pablos MV, Oritz JA, Tarazona JV (2000) A system dynamic model for the assessment of different exposure routes in aquatic ecosystems. Sci Total Environ 247:107-118

Chaumont F, Barrieu F, Wojcik E, Chrispeels MJ, Jung R (2001) Aquaporins constitute a large and highly diverse protein family in maize. Plant Physiol (Rockv) 125: 1206-1215

Chiou CT, Schemedding DW, Manes M (1982) Partitioning of organic compounds in octanol-water systems. Environ Sci Technol 16:4-10

Chu W, Chan KH (2000) The prediction of partitioning coefficients for chemicals causing environmental concern. Sci Total Environ 248:1-10

Closs EI, Scheld JS, Sharafi M, Forstermann U (2000) Substrate supply for nitric oxide synthase in macrophages and endothelial cells: role of catonic amino acid transporters. Mol Pharmacol 57:68-74

Coates M, Connell DW, Barron D (1985) Aqueous solubility and octanol-1-ol water partition coefficients of aliphatic hydrocarbons. Environ Sci Technol 19:628-632

Coats JR, Symonik SP, Bradbury SP, Dyer SD, Timson LK, Atchinson GT (1989) Toxicology of synthetic pyrethroids in aquatic organisms: an overview. Environ Toxicol Chem 8:671-679

Collavini F, Zonta R, Novelli A, Luca Z (2000) Heavy metals behaviour during resuspension of the contaminated anoxic sludge of the Venice canals. Toxicol Environ Chem 77:171-187

Connell DW (1988) Bioaccumulation behaviour of persistent organic chemicals with aquatic organisms. Rev Environ Toxicol Chem 101:117-154

Connell DW (1990) Bioaccumulation of xenobiotic compounds. CRC Press, Boca Raton, FL

Connell DW, Bycroft B (1990) Occurrence and behaviour of toxicants. In: Davie P, Stock E, Low Choy D (eds) The Brisbane River: a source-book for the future. Australian Littoral Society and Queensland Museum, Brisbane, p 313-318

Connell DW, Bowman M, Hawker D (1988a) Bioconcentration of chlorinated hydrocarbons from sediments by oligochaetes. Ecotoxicol Environ Saf 16:293-302

Connell DW, Wu RSS, Richardson BJ, Leugn K, Lam PSK, Connell PA (1988b) Fate and risk evaluation of persistent organic contaminants and related compounds in Victoria Harbour, Hong Kong. Chemosphere 36:2019-2030

Connell DW, Braddock RD, Main SV (1993) Predictions of the partitioning coefficient of lipophilic compounds in the airmammal tissue system. Sci Total Environ Suppl Pt 2: $1383-1396$

Cserháti T, Forgács E, Oros G (2002) Biological activity and environmental impact of anionic surfactants. Environ Int 28:337-348

Cunningham JC (1992) Textbook of veterinary physiology. Saunders, Sydney 
Dang DN, Carvalho FP, Nguyun MA, Nguyun QT, Nguyun THY, Villeneuve JP, Cattini C (2001) Chlorinated pesticides and PCBs in sediments and molluscs from freshwater canals in the Hanoi region. Environ Pollut 112:311-320

Datry T, Malard L, Vitry L, Hervant JG (2003) Solute dynamics in the bed sediments of a stormwater infiltration basin. J Hydrol (Amst) 20:1-17

De la Torre AI, Fernándz C, Tarazona JV, Munoz I (1995) Detection of aroclor, DDT, malathion and HCB using semipermeable membranes as concentration method. Chemosphere 31:2727-2737

Depwer DJ, Weber BH (1996) Darwinism evolving: systems dynamics and the geneology of natural selection. Massachusetts Institute of Technology Press, Cambridge

Di Toro DM, Dodge LM, Hand VC (1990) A model for nonionic surface sorption. Environ Sci Technol 24:1013-1020

Di Toro DM, Zarba CS, Hansen DJ, Berry WJ and 5 others (1991) Technical basis for establishing sediment quality criteria for non-ionic organic chemicals using equilibrium partitioning. Environ Toxicol Chem 10:1541-1583

Doyle CJ, Pablo F, Lim RP, Hyne RV (2003) Assessment of metal toxicity in sediment pore water from Lake Macquarie, Australia. Arch Environ Contam Toxicol 44:343-350

Drenner R (1993) Effects of sediment-bound bifenthrin on gizzard shad and planktonic organisms in experimental tank mesocosms. Environ Toxicol Chem 12:1297-1306

Ellis JB, Neish B, Trett MW, Best JG, Weightman AJ, Morgan P, Fry JC (2001) Comparison of microbial and meiofaunal community analyses for determining impact of heavy metal contamination. J Microbiol Methods 45:117-185

Fenchel T (1970) Studies on the decomposition of organic detritus derived from the turtle grass Thalassia testudinum. Limnol Oceanogr 15:14-20

Fent K (2003) Ecotoxicological problems associated with contaminated sites. Toxicol Lett:1-13

Ferraro SP, Cole FA (1997) Effects of DDT sediment-contamination on macrofaunal community structure and composition in San Francisco Bay. Mar Biol 130:323-334

Fisk AT, Hobson KA, Norstrom RJ (2001) Influence of chemical and biological factors on trophic transfer of persistent organic pollutants in the Northwater Polynya marine food web. Environ Sci Technol 35:732-738

French-Constant RH, Rocheleau TA, Steichen JC, Chalmers AE (1993) A point mutation in a Drosophila GABA receptor confers insecticide resistance. Nature 363:449-451

Garcia F, Kierbel A, Larocca MC, Gradilone SA, Splinter P, LaRusso NF, Marinelli RA (2001) The water channel aquaporin-8 is mainly cellular in rat hepatocytes, and its plasma membrane insertion is stimulated by cyclic AMP. J Biol Chem 276:12147-12152

Gerencser GA, Cattey MA, Ahern GA (1995) Sufate-oxalate exchange in the lobster hepatopancreatic basolateral membrane vesicles. Am J Physiol 38:R572-R577

Gili JM, Coma R (1998) Benthic suspension feeders: their paramount role in littoral marine food webs. Trends Ecol Evol 13:316-321

Grumiaux F, Lepretre A, Dhainaut-Courtois N (1998) Effects of sediment quality on benthic macroinvertebrate communities in streams of north France. Hydrobiologia 385: $33-46$

Guruge KS, Tanabe S (2001) Contamination by persistent organochlorines and butyltin compounds in the west coast of Sri Lanka. Mar Pollut Bull 42:179-186

Halling-Sørensen B, Nyholm N, Kusk KO, Jacobsson E (2000) Influence of nitrogen status on the bioconcentration of hydrophobic organic compounds to Selenastrum capricornutum. Ecotoxicol Environ Saf 45:33-42
Hamer MJ, Goggin UM, Muller K, Maund SJ (1999) Bioavailability of lambda-cyhalothrin to Chironomus rivarius in sediment-water and water-only systems. Aquat Ecosyst Health Manag 2:403-412

Hawker DW, Connell DW (1985) Relationships between partitioning coefficients, uptake rate constant, clearance rate constant and time to equilibrium for bioaccumulation. Chemosphere 14:1205-1219

Hawker DW, Connell DW (1986) Bioconcentration of lipophilic compounds by some aquatic organisms. Ecotoxicol Environ Saf 11:184-197

Hawker DW, Connell DW (1988a) Influence of partitioning coefficient for lipophilic compounds on bioconcentration kinetics of fish. Water Res 22:701-707

Hawker DW, Connell DW (1988b) Octanol-water partitioning coefficients of polychlorinated biphenyl congeners. Environ Sci Technol 22:328-337

Hendriks AJ, van der Linde A, Cornelissen G, Sijm DT (2001) The power of size. 1. Rate constants and equilibrium ratios for accumulation of organic substances related to octanolwater partitioning ratio and species weight. Environ Toxicol Chem/SETAC 20:1399-1420

Hoskings D, Stancky SE, Decho AW (2003) Utilization of algal and bacterial extracellular polymeric secretions (EPS) by the deposit-feeding brittlestar, Amphipholis gracillima (Echinodermata). Mar Ecol Prog Ser 247:93-101

Housi AM, Baylis AM, Buckingham SD, Sattelle DB (1995) Actions of the insecticide fipronil on dieldrin-sensitive and -resistant GABA receptors of Drosophila melanogaster. Br J Pharmacol 115:909-912

Hu HP, Wu MX (2001) Mechanisms of anaesthetic action: oxygen pathway perturbation. Med Hypoth 57:619-627

Hund-Rinke K, Kordel W (2003) Underlying issue in bioaccessibility and bioavailability: experimental methods. Ecotoxicol Environ Saf 56:52-56

Hursthouse AS, Matthews JM, Figures JE, Iqbal-Zahid P, Davises IM, Vaughan DH (2003) Chromium in intertidal sediments of the Clyde, UK: potential for remobilisation and bioaccumulation. Environ Geochem Health 25: 171-203

Hutchings PA, Saenger P (1987) Ecology of mangroves. University of Queensland Press, Brisbane

Just AC, Hawker DW, Connell DW (1990) Partitioning of lindane between sediment, water and the crustacean Metapenaeus macleayi. Aust J Mar Freshw Res 41:389-397

Kamp F, Guo W, Souto R, Corkey BE, Hamilton JA (2002) Rapid flip-flop of oleic acid across the plasma membrane of adipocytes. J Biol Chem 278:7988-7995

Kanda T, Ono T, Matsubara Y, Muto T (1990) Possible role of rat fatty-acid binding proteins in the intestine as carriers of phenol and phthalate esters. Biochem Biophys Res Commun 168:1053-1058

Karrupiah M, Gupta G (1996) Impact of point source and nonpoint source pollution on pore waters of two Chesapeake Bay tributaries. Ecotoxicol Environ Saf 35:81-85

Kaufman SS, Lyden ER, Marks WH, Lieberman J and 5 others (2001) Lack of utility of intestinal fatty acid binding proteins levels in predicting intestinal tissue allograft rejection. Transplantation 71:1058-1060

Konzo D, Ding X, Iwasaki I, Meng X, Kamagata Y, Agre P, Kitagwa Y (2003) Functional expression and characterisation of an archeal aquaporin AqpM from Methanothermobacter marburgensis. J Biol Chem 278:10649-10656

Kostaropoulos I, Athanasios IP, Metaxakis A, Boukouvala E, Papadopoulou-Mourkidou E (2001) Glutathione S-transferase in the defence against pyrethroids in insects. Insect Biochem Mol Biol 31:313-319 
Krantzberg G, Reynoldson T, Jaagumagi R, Bedard D, Painter S, Boyd D, Pawson T (2000) SEDS: setting environmental decisions for sediment, a decision making tool for sediment management. Aquat Ecosyst Health Manag 3: 387-396

Kujawinski EB, Farrington JW, Mofett JW (2000) Importance of passive diffusion in the uptake of polychlorinated biphenyls by phagotrophic protozoa. Appl Environ Microbiol 66:1987-1993

Lahr J, Maas-Diepeveen JL, Stuijfzand SC, Leonards PE and 6 others (2002) Responses in sediment bioassays used in the Netherlands: can observed toxicity be explained by routinely monitored priority pollutants? Water Res 37: $1691-1710$

Lawrence AI, Mason RP (2001) Factors controlling the bioaccumulation of mercury and methylmercury by the estuarine amphipod, Letocheirus plumulosus. Environ Pollut 111:217-231

Li WI, Berman FW, Okino T, Yokokawa F, Shioiri T, Gerwick WH, Murray TF (2001) Antillatoxin is a marine cyanobacterial toxin that potentially activates voltage-gated sodium channels. Proc Natl Acad Sci USA 98:7599-7604

Lillebø AI, Flindt MR, Pardal MA, Marques JC (1999) The effect of macrofauna, meiofauna and microfauna on the degradation of Spartine maritima detritus from a salt marsh area. Acta Oecol 20:249-258

Liu Z, Valles SM, Dong K (2000) Novel point mutations in the German cockroach para sodium channel gene are associated with knockdown resistance (kdr) to pyrethroid insecticides. Insect Biochem Mol Biol 30:991-997

Lodish H, Berk A, Zipursky SL, Matsudia P, Baltimore D, Darnell J (2000) Molecular cell biology. WH Freeman, New York

Madigan MT, Martinko JM, Parker J (2003) Brock biology of microorganisms, 10th edn. Prentice Hall, Englewood Cliffs, NJ

Markwell RD, Connell DW, Gabric AJ (1989) Bioaccumulation of lipophilic compounds from sediments by oligochaetes. Water Res 23:1443-1450

Marples D (2001) Aquaporins: roles in renal function and peritoneal dialysis. Perit Dial Int 2001 21:212-218

Maskaoui K (2002) Measurement of heavy metal speciation over redox gradients in natural water-sediment interfaces and implications for uptake by benthic organisms. Environ Sci Technol 36:5130-5138

Maskaoui K, Zhou JL, Hong HS, Zhang ZL (2002) Contamination by polycyclic aromatic hydrocarbons in the Jiulong River Estuary and Western Xiamen Sea, China. Environ Pollut 118:109-122

Meador JP, Casillas E, Sloan CA, Varanasi U (1995) Comparative bioaccumulation of polycyclic aromatic hydrocarbons from sediment by two infaunal invertebrates. Mar Ecol Prog Ser 123:107-124

Miller G (2000) Analytical report for the Australian Marine Conservation Society. Envirotest, Brisbane

Mitra S, Dickhut RM (1999) Three-phase modelling of polycyclic aromatic hydrocarbon associated with pore-waterdissolved organic carbon. Environ Toxicol Chem 18: $1144-1148$

Mitragotri S (2002) Modeling skin permeability to hydrophilic and hydrophobic solutes based on four permeation pathways. J Control Release 86:69-92

Moriarty F (1988) Ecotoxicology: the study of pollutants in ecosystems. Academic Press, Sydney

Morrisey DJ, Underwood AJ, Howitt L (1996) Effects of copper on the faunas of marine soft-sediments: an experimental field study. Mar Biol 125:199-213
Mortimer RJG, Davey JT, Krom MD, Watson PG, Frickers PE, Clifton RJ (1999) The effect of macrofauna on pore water profiles and nutrient fluxes in the intertidal zone of the Humber estuary. Estuar Coast Shelf Sci 48:683-699

Munoz MJ, Ramos C, Tarazona JV (1996) Bioaccumulation and toxicity of hexachlorobenzene in Chlorella vulgaris and Daphnia magna. Aquat Toxicol 35:211-220

Murphy CR, Janszen DB, Gargas ML (1995) An in vitro method for determination of tissue partitioning coefficients of non-volatile chemicals such as 2,3,7,8-tetrachlorodibenzo-p-dioxin and estradiol. J Appl Toxicol 15: 147-152

Nascimento A, Smith, DH, Pereira M, de Aruja S, Silva M, Mariani A (2000) Integration of varying responses of different organisms to water and sediment quality at sites impacted and not impacted by the petroleum industry. Aquat Ecosyst Health Manag 3:449-458

Neal C, House WA, Whitton BA, Leeks GLJ (1998) Conclusions to special issue: water quality and biology of United Kingdom Rivers entering the North Sea: the land ocean interaction study (LOIS) and associated work. Sci Total Environ 210/211:585-594

Nejsum LN, Kwon TH, Marpels D, Flyvbjerg A, Knepper MA, Frokiaer J, Neilson S (2001) Compensatory increase in AQP2, p-APQ2, and AQP3 expression in rats with diabetes mellitus. Am J Physiol Renal Physiol 280:F715-726

Nipper M (2000) Current approaches and future directions for contaminant-related impact assessments in coastal environments: Brazilian perspective. Aquat Ecosyst Health Manag 3:433-447

Nipper M, Carr RS, Biedenbach JM, Hooten RL, Miller K (2002) Toxicological and chemical assessment of ordnance compounds in marine sediments and pore waters. Mar Pollut Bull 44:789-806

Odum EP (1971) Fundamentals of ecology. WB Saunders, London

Paden E, Venturi M, Gerchman Y, Dover N (2001) $\mathrm{Na}\left(^{+}\right) / \mathrm{H}\left(^{+}\right)$ antiporters. Biochim Biophys Acta 1505:144-157

Park SS, Park JW, Uchrin C, Cheney MA (2002) A micelle inhibition model for the bioavailability of polycyclic aromatic hydrocarbons in aquatic ecosystems. Environ Toxicol Chem 21(12):2737-2741

Patton JS (ed) (1981) Gastrointestinal lipid digestion. Raven, New York

Peltier EF, Webb SM, Gillard JF (2003) Zinc and lead sequestration in an impacted wetland system. Adv Environ Res 8:103-112

Periera WE, Rostad CE, Chiou CT, Brinton TI, Barber II, Demcheck DK, Demas CR (1988) Contaminated estuarine waters, biota and sediments by halogenated organic compounds: a field study. Environ Sci Technol 22:772-778

Peso-Aguiar MC, Smith DH, Assis RCF, Santa-Isabel LM and 9 others (2000) Effects of petroleum and its derivatives in benthic communities at Baia de Todos os Santos/Todos os Santos Bay, Bahia, Brazil. Aquat Ecosyst Health Manag 3: 459-470

Peters GM, Maher WA, Krikowa F, Roach AC, Jeswani HK, Barford JP, Gomes VG, Reible DD (1999) Selenium in sediments, pore waters and benthic infauna of Lake Macquarie, New South Wales, Australia. Mar Environ Res 47: 491-508

Petit JM, van Wuytswinkel O, Briat JF, Lobreaux S (2001) Characterisation on an iron-dependant regulatory sequence involving the transcription control of AtFer 1 and ZnFer 1 plant ferritin gene ion. J Biol Chem 276: 5584-5590

Quintero FJ, Blatt MR (1997) A new family of $\mathrm{K}^{+}$transporters 
from Arabidopsis that are conserved across phyla. FEBS Lett 415:206-211

Raggers RJ, Pomonsrski T, Holthius JCM, van Meer G (2002) Lipid traffic: the $\mathrm{ABC}$ of transbilayer movement. Traffic 1 : 226-234

Rajagopal A, Simon SM (2003) Subcellular localisation and activity of multidrug resistance proteins. Mol Biol Cell 14(8):3389-3399

Randall DJ, Connell DW, Yang R, Wu SS (1998) Concentrations of persistant lipophilic compounds in fish are determined by exchange across the gills, not through food chains. Chemosphere 37:1263-1270

Ranson H, Jensen B, Vulule JM, Wang X, Hemingway J, Collins FH (2000) Identification of point mutation in voltage-gated sodium channel gene of Kenyan Anopheles gambiae associated with resistance to DDT and pyrethroids. Insect Mol Biol 9:491-497

Raven PH, Evert RF, Eichhorn SE (1992) Biology of plants, 5th edn. Worth Publishers, New York

Ren XQ, Furukawa T, Chen ZS, Okumura H and 6 others (2000) Functional composition between YCF1 and MRP1 expressed in Sf21 insect cells. Biochem Biophys Res Commun 270:608-615

Retnakaren A, Gelbic I, Sundaram M, Tomkins W and 6 others (2001) Mode of action of the ecdysone against tebulfenozide (RH-5992) and an expression of exclusion mechanism to explain resistance to it. Pest Manag Sci 57: 951-957

Roach AC, Jones AR, Murray A (2001) Using benthic recruitment to assess the significance of contaminated sediments: the influence of taxonomic resolution. Environ Pollut 112:131-143

Roitt IR (1994) Essential immunology. Blackwell Scientific Publications, Melbourne

Ruus A, Ugland KI, Espeland O, Skaare JU (1999) Organochlorine contaminants in a local marine food chain from Jarfjord, Norway. Mar Environ Res 48:131-146

Sansom MS, Law RJ (2001) Membrane proteins: aquaporins - channels without ions. Curr Biol 11:R71-73

Schäfer G, Purschke W, Schmidt CL (1996) On the origin of respiration: electron transport proteins from archaea to man. FEMS Microbiol Rev 18:173-188

Scheifler R, Brahmin B, Gomot-de Vaufleury A, Cranus JM (2002a) A field method using microcosms to evaluate transfer of $\mathrm{Cd}, \mathrm{Cu}, \mathrm{Ni}, \mathrm{Pb}$ and $\mathrm{Zn}$ from sewage sludge amended forest soils to Helix aspersa snails. Environ Pollut 122:343

Scheifler R, Gomot-de Vaufleury A, Toussaint ML, Bardot PM (2002b) Transfer and effects of cadmium in an experimental food chain involving the snail Helix aspersa and the predatory carabid beetle Chrysocarabus splendens. Chemosphere 48:571-579

Scheifler R, Brahmin B, Gomot-de Vaufleury A, Cranus JM, Bardot PM (2003) A field method using microcosoms to evaluate transfer of $\mathrm{Cd}, \mathrm{Cu}, \mathrm{Ni}, \mathrm{Pb}$ and $\mathrm{Zn}$ from sewage sludge amended forest soils to Helix apsersa snails. Environ Pollut 122:343-350

Schinkel AH, Smit JJ, van Tellingen O, Beijen JH and 6 others (1994) Disruption of the mouse mdr1a P-glycoprotein gene leads to a deficiency in the blood-brain barrier and to increased sensitivity to drush. Cell 20:491-502

Schramm KW, Behechti A, Beck B, Kettrup A (1998) Influence of an aquatic humic acid on the bioconcentration of selected compounds in Daphnia magna. Ecotoxicol Environ Safety 41:73-76

Senthilkumar K, Kannan K, Subramanian A, Tanabe S (2001) Accumulation of organochlorine pesticides and polychlo- rinated biphenyls in sediments, aquatic organisms, birds, bird eggs and bat collected from south India. Environ Sci Pollut Res Int 8:35-47

Siegfried BD (1993) Comparative toxicity of pyrethroid insecticides to terrestrial and aquatic insects. Environ Toxicol Chem 12:1683-1693

Skoglund RS, Strange K, Swackhamer DL (1996) A kinetics model for predicting the accumulation of PCBs in phytoplankton. Environ Sci Technol 30:2113-2120

Skrabal SA, Terry CM (2002) Distributions of dissolved titanium in porewaters of estuarine and coastal marine sediments. Mar Chem 77:109-122

Slimko EM, Lester HA (2003) Codon optimization of Caenorhabditis elegans $\mathrm{GluCl}$ ion channel genes for mammalian cells dramatically improves expression levels. J Neurosci Methods 124:75-81

Smital T, Sauerborn R, Pivcevic B, Krca S, Kurelec B (2000) Interspecies differences in $\mathrm{P}$-glycoprotein mediated activity of multixenobiotic resistance mechanism in several marine and freshwater invertebrates. Comp Biochem Physiol Pharmacol Toxicol Endocrinol 126:175-186

Smith JM, Pritchard RK (2002) Localization of p-glycoprotein mRNA in the tissues of Haemonchus contortus adult worms and its relative abundance in drug-selected and susceptible strains. J Parasitol 88:612-620

Stenerson J (1992) Uptake and metabolism of xenobiotics by earthworms. In: Greig-Smith PW, Becker H, Edwards PT, Heimbach (eds) Ecotoxicology of earthworms. Intercept Press, Andover, UK, p 129-138

Stephenson W, Campbell BM (1977) The macrobenthos of Serpentine Creek. Mem Queensl Mus 18:75-93

Stevens BR, Tellier M, Harvey W, Feldman DH, Bosworth J (2000) Interleukin-2 and concanavalin A upregulate a cat 2 iosoform encoding high affinity L-argenine cotransporter in feline lymphocytes. Can Vet Res 64:187-191

Stewart PM, Butcher JY, Swinford TO (2000) Land use, habitat, and water quality effects on macroinvertebrate communities in three watersheds of a Lake Michigan associated marsh system. Aquat Ecosystem Health Manag 3: 179-189

Sue MS, Liu KM, Yu HS (1993) The gastro-intestinal adsorption of griseofulvin can be enhanced by encapsulation into liposomes. Kao-Hsiung I Hsueh K'o Hsueh Tsa Chih 9:1-8

Sun Y, Ramirez J, Woski SA, Vincent JB (2000) The binding of trivalent chromium to low-molecular-weight chromiumbinding substance (LMWCr) and the transfer of chromium from transferrin and chromium picolinate to LMWCr. J Biol Inorg Chem 5:129-136

Tagatz ME, Stanley RS, Plaia G, Deans CH (1987) Response of estuarine macroinfauna colonizing sediments contaminated with fenvalerate. Environ Toxicol Chem 6:21-25

Thumser AE, Storch J (2000) Liver and intestinal fatty acidbinding proteins obtain fatty acids from phospholipid membranes by different mechanisms. J Lipid Res 41: 647-656

Tilquin M, Peltier JP, Marigo G (2000) Mechanism for the coupling of iron and glyphosate uptake in Catharanus roseus. Pestic Biochem Physiol 67:145-154

Trapp S, Miglioranza SB, Mosbaek H (2001) Sorption of lipophilic organic compounds to wood and implications for their fate. Environ Sci Technol 35:1561-1566

Turner A, Millward GE (2002) Suspended particles: their role in estuarine biogeochemical cycles. Estuar Coast Shelf Sci 55:857-883

Ueda I, Matsuk IH (2000) Centennial for the Meyer-Overton rule: anasthetics and receptors. Masui 49:114-120

Umbenhauer DR, Lankas GR, Pippet TR, Wise D, Cartwright 
ME, Hall SJ, Beare C (1997) Identification of a P-glycoprotein deficient subpopulation in the CF-1 mouse strain usinga restriction fragment length polymorphism. Toxicol Appl Pharmacol 146:88-94

University of North Carolina (UNC) (1994) Weak link in the food chain. University of North Carolina Coastal Study, UNC, Chapel Hill, NC

Van Beelan P, Fleuren-Kemila AK (1997) Influence of pH on the toxic effects of zinc, cadmium, and pentachlorophenol on pure cultures of soil microorganisms. Environ Toxicol Chem 16:146-153

Van De Graaff KM, Fox SI (1992) Concepts of human anatomy and physiology. William C Brown, Dubuque, IA

Van der Oost R, Beyer J, Vermeulen NPE (2003) Fish bioaccumulation and biomarkers in environmental risk assessment: a review. Environ Toxicol Pharmacol 13:57-149

van Veen HW, Margolles A, Müller M, Higgins CF, Konings WN (2000) The homodimeric ATP-binding cassette transporter LmrA mediates multidrug transport by an alternating two-site (two-cylinder engine) mechanism. EMBO (Eur Mol Biol Organ) J 19:2503-2514

Vijver MG, Vink JPM, Miermans CJH, van Gestel C (2002) Oral sealing using glue: a new method to distinguish between intestinal and dermal uptake of metals in earthworms. Soil Biol 10:1-8

Voet D, Voet JG, Pratt CW (1999) Fundamentals of biochemistry. John Wiley \& Sons, Brisbane

Weis JS, Weis P (1992) Transfer of contaminants from CCAtreated lumber to aquatic biota. J Exp Mar Biol Ecol 161: 189-199

Weltje L, Heidenreich H, Zhu W, Wolterbeek HT, Krohammer S, de Goeji JJM, Markert B (2002) Lanthanide concentra-

Editorial responsibility: Otto Kinne (Editor),

Oldendorf/Luhe, Germany tions in freshwater plants and molluscs related to those in surface water, pore water and sediment: a case study in The Netherlands. Sci Total Environ 286:191-214

Williams RJP, Fraústo Da Silva JJR (2003) Evolution was chemically constrained. J Theor Biol 220:323-343

Williamson KS, Petty JD, Huckins JN, Leob JA, Kaiser EM (2002) Sequestration of priority pollutant PAHs from sediment pore water employing semipermeable membrane devices. Chemosphere 49:717-729

Wolff M, Koch V, Isaac V (2000) A trophic flow model of the Caete mangrove estuary (North Brazil) with considerations for the sustainable use of its resources. Estuar Coast Shelf Sci 50:789-803

Wong CKC, Yeung HY, Woo PS, Wong MH (2001) Specific expression of cytochrome P4501A1 gene in gill, intestine and liver of tilapia exposed to coastal sediments. Aquat Toxicol 54:69-80

Xu FL, Dawson RW, Tao S, Li BG, Cao J (2002) System-level responses of lake ecosystems to chemical stresses using energy and structural changes as ecological indicators. Chemosphere 46:173-185

Zabetoglou K, Voutsa D, Samara C (2002) Toxicity and heavy metal contamination of surficial sediments from the Bay of Thessaloniki (northwestern Aegean Sea) Greece. Chemosphere 49:17-26

Zeuthen T, Meinild AK, Loo DD, Wright EM, Klaerke DA (2001) Isotonic transport by the $\mathrm{Na}^{+}$- glucose cotransporter SGLT1 from humans and the rabbit. J Physiol 531: 361-374

Zhou JL, Hong H, Zhang Z, Maskaoui K, Chen W (2000) Multi-phase distribution of organic micropollutants in Xiamen Harbour, China. Water Res 34:2132-2150

Submitted: October 8, 2003; Accepted: February 19, 2004

Proofs received from author(s): June 14, 2004 